\title{
Daughters learn about the library
}

By Mary N. Hernandez and Christine Kollen

\section{Take Our Daughters to Work Day at the University of Arizona}

ne of the values of the University of Arizona (UA) Library is diversity. When the UA Diversity Council sent out a request for assistance with the universitywide initiative to support Take Our Daughters to Work Day, it was supported by the library dean's cabinet and library employees.

Take Our Daughters to Work Day (TODWD) was begun in 1993. It was sponsored by the Ms. Foundation for Women after disturbing findings on the development of adolescent girls became available.

Studies by Harvard University researchers, the American Association of University Women (AAUW), and the Minnesota Women's Fund indicate that during adolescence girls often receive less attention than boys in school and in youth-serving programs, suffer from lower expectations than do their male counterparts, and tend to like or dislike themselves based on aspects of their physical appearance.

Held nationally on the fourth Thursday in April (and in 14 countries around the world), TODWD involves millions of girls between the ages of nine and 15 who go to work with adult mentors--parents, grandparents, cousins, aunts, and friends - to learn firsthand the exciting range of life options open to them, while getting the attention they deserve.

Beginning in 1994, the UA Library joined with the UA Diversity Action Council in sponsoring the national TODWD. The authors, members of the University Library Diversity Coun- cil, agreed to coordinate the university library portion and, with the University Diversity Council, planned a series of campus activities which included introducing students (and some of their parents) to the library.

The university library has two electronic classrooms, one in the Main Library and one in the Science Library, each equipped with 14 computer stations. Each classroom has a seating capacity of 42. At the time of the library's first involvement with TODWD, the electronic classroom in the Main Library was PC-based and the one in the Science Library was Mac-based. Once logged into the different systems, there is no perceptible difference in accessing various $\mathrm{da}$ tabases. Now both classrooms are PC-based.

\section{The first year: 1994}

Because SABIO, the library online catalog, was relatively new, the first year program included teaching students how to use it and how to access the Internet and the commercial journal databases to which the library system was linked. Two one-hour sessions were scheduled, one in the morning and one in the afternoon at each site. Time was scheduled for students to experiment. Members of the Library Diversity Council staffed each session. This provided maximum opportunity for the students to choose what they wanted to do from among all the special activities offered on campus.

The first session was more successful than imagined. Not only daughters, but parents came and were invited to sit at the back of the classroom. The second session, scheduled for midafternoon, did not attract as many visitors but was still a full session. This time each daughter was able to work singly at a terminal. 


\section{High Society. Ice Cream Socials. Gang Wars. Fighting Words.}

Human society has countless manifestations and meanings. We track them, and provide you with thousands of references to enhance your research.

Sociological Abstracts (SA), Social Planning/Policy \& Development Abstracts (SOPODA) and Linguistics and Language Behavior Abstracts (LBA) contain a spectrum of information directly related to your areas of interest and expertise.

Drawing from more than 2,400 journals published in 35 countries, we present abstracts of articles, books and conference papers. Our bibliographic entries will guide you to relevant dissertations and important book and other media reviews. All are expertly indexed and classified for easy access.

SA, SOPODA and LLBA are available in a variety of media: print, online, CD-ROM, and magnetic tape.

Let us help you discover the social worlds and patterns of communication by which we live.

SAl's Web site, located at WwW. socabs.org, contains searchable subsets of the SA, SOPODA, and LLBA databases, hot topics, the Note Us newsletter, and links to other relevant sites and resources.

For more information on our products and services, visit our Web site, or contact us at:

\section{sociological abstracts, inc.}

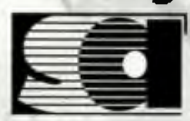

P.0. Box 22206, San Diego, CA 92192-0206

619.695.8803 Fax 619.695.0416

Internet: socio@cerfnet.com

Web site http://www.socabs.org

SAl products are available in print; online from Knight-Ridder, DIMDI, OCLC and Ovid; on CD-ROM from SilverPlatter, EBSCO, Ovid and NISC; and on magnetic tape directly from SAI. For document delivery contact

SOCIOLOGY* Express at

619.695 .8803 or Fax 310.208.2982.

\section{The second year: 1995}

In 1995, because the library offered more electronic resources, the TODWD library sessions were scheduled for 90 minutes. The library had access to a CD-ROM Local Area Network (LAN) and more commercial journal databases in the electronic classrooms. Less time was spent on SABIO instruction and more on CD-ROM databases and the Internet. Again, time was included for the participants to experiment.

This time a call went out to all staff explaining the purpose of the library's involvement and asking for volunteers to help staff the sessions. Several staff members were enthusiastic and agreed to assist in both electronic classrooms. Again, an impressive number of daughters and parents took advantage of the opportunity to learn more about the library and what was available electronically. Feedback indicated the daughters enjoyed the session but wanted more hands-on time.

\section{The third year: 1996}

In 1996, with the impact of the World Wide Web, and since so many of the students had become familiar with the electronic library, it was decided to use the TODWD to identify educational, financial, and fun sites on the Web for the daughters to explore. The presentation offered students new options on the uses of the Internet. Not only was the UA homepage available, but also those of colleges and universities throughout the country. These sites included liberal arts colleges, research level one universities, and discipline-focused institutions.

Sites that had financial information were included because some of the students were nearing time for college application. It is indicative of the times that these sites were used and examined the longest.

The 1996 TOIDW library handout was a listing of the Web sites which were targeted as potentially helpful to the students.

One thing is certain, the Information Superhighway has many passengers, and each year the library will have to find new ways to stay ahead of what students know, while trying to anticipate what students will need.

\section{Future direction}

What is on the agenda for this year? Four sessions are planned: two on how to navigate the Internet, including how to find materials in the library, and two on how to create and maintain a homepage. 